\title{
Penerapan Data Mining Algoritma C4.5 dalam Menentukan Rekam Jejak Kinerja Dosen STT Harapan Medan
}

\author{
Rismayanti \\ ${ }^{1}$ Program studi teknik informatika, \\ Universitas Harapan Medan \\ risma.stth@gmail.com
}

\author{
Fera Damayanti \\ ${ }^{2}$ Program studi teknik informatika, \\ Universitas Harapan Medan \\ feradamayantii@gmail.com
}

\author{
Khairunnisa \\ ${ }^{3}$ Program studi teknik informatika, \\ Universitas Harapan Medan \\ khairunnisajv2@gmail.com
}

\begin{abstract}
Kinerja kerja dosen merupakan suatu hal yang sangat penting dalam upaya lembaga perguruan tinggi untuk mencapai tujuannya. oleh karena itu perguruan tinggi perlu melakukan evaluasi dan penilaian yang menggambarkan kinerja dosen sebagai prestasi kerja yang dihasilkan oleh dosen tersebut sesuai dengan peranannya. Evaluasi dan penilaian kinerja dosen yang dilakukan di STT Harapan masih belum maksimal sehingga tingkat kesadaran setiap dosen untuk meningkatkan kinerjanya juga tidak maksimal. Penelitian ini bertujuan menerapkan data mining algoritma $C 4.5$ dalam menentukan rekam jejak kinerja dosen berdasarkan 3 atribut input(publikasi, pengabdian dan pengajaran) dan 1 atribut output yang bernilai kinerja "kurang" "cukup" dan "tinggi". Hasil penelitian berupa decision tree beserta rules yang memberikan informasi hasil evaluasi kinerja dosen STT Harapan Medan dalam melaksanakan tri darma perguruan tinggi.
\end{abstract}

Kata Kunci-Data Mining; Algoritma C4.5; Decision Tree

\section{PENDAHULUAN}

Kinerja dosen pada suatu perguruan tinggi merupakan prilaku nyata yang ditampilkan setiap dosen sebagai prestasi kerja yang dihasilkan oleh dosen tersebut sesuai dengan peranannya. Penilaian kinerja dosen merupakan suatu proses di mana lembaga melakukan penilaian terhadap kinerja dosen dan mengevaluasi hasil pekerjaan dosen. Ada berbagai cara dalam melakukan evaluasi dan penilaian kinerja dosen, dan di STT Harapan evaluasi dan penilaian kinerja dosen yang dilakukan adalah dengan cara pengisian angket oleh mahasiswa yang menilai kinerja dosen dalam hal pengajaran. Hal tersebut tentunya masih belum maksimal dalam melakukan evaluasi dan penilaian terhadap kinerja dosen, akibat nya muncul permasalahan di mana dosen di STT Harapan tidak memperoleh umpan balik yang maksimal dari lembaga atas hasil kerja mereka sehingga tingkat kesadaran setiap dosen untuk meningkatkan kinerjanya juga tidak maksimal baik itu dalam hal kinerja tri darma perguruan tinggi maupun prestasi hasil kerja lainnya.

Data Mining Algoritma C4.5 cocok digunakan untuk membentuk decision tree yang berguna untuk mengeksplorasi data dan menemukan hubungan yang tersembunyi antara sejumlah variabel input dengan satu variabel target. Penerapan Data Mining Algoritma C4.5 dalam menggali informasi terhadap data-data yang berkaitan dengan kinerja dosen di STT Harapan, yang meliputi data diri dosen, kinerja dosen di bidang tri darma perguruan tinggi akan berpotensi menghasilkan informasi baru yang berguna bagi STT Harapan dalam melakukan 
evaluasi dan penilaian terhadap kinerja dosen. Selain itu dosen diharapkan dapat lebih termotivasi dalam meningkatkan kinerja kerja sehingga dapat mempermudah dalam mengajukan usulan kenaikan jabatan fungsional maupun serdos.

\section{TINJAUAN PUSTAKA}

\section{A. Data Mining}

Secara sederhana Data Mining adalah penambangan atau penemuan informasi baru dengan mencari pola atau aturan tertentu dari sejumlah data yang sangat besar. Data Mining merupakan proses iteratif dan interaktif untuk menemukan pola atau model baru yang dapat digeneralisasi untuk masa yang akan datang, bermanfaat dan dapat dimengerti dalam suatu database yang sangat besar(massive database)[4]. Data mining disisi lain adalah kegiatan meliputi pengumpulan, pemakaian data historis untuk menemukan keteraturan, pola atau hubungan dalam set data berukuran besar[9].

Sebagai suatu rangkaian proses, Data Mining dapat dibagi menjadi beberapa tahap. Tahap-tahap tersebut bersifat interaktif di mana pemakai terlibat langsung atau dengan perantara knowledge base[10], terlihat pada gambar di bawah ini.

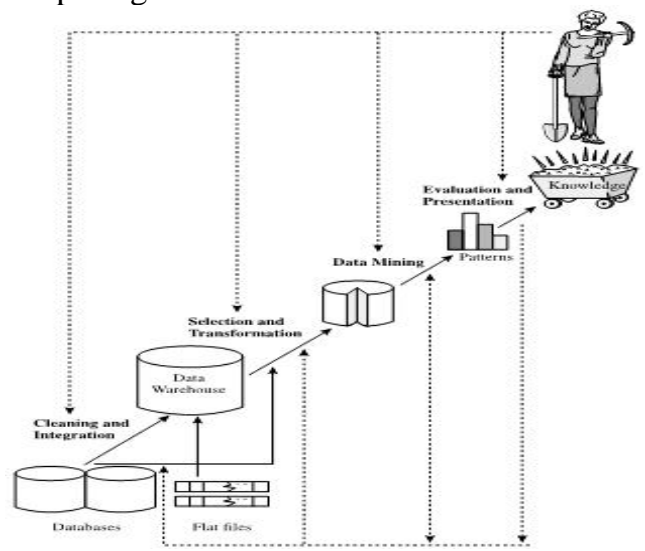

Gambar 1. Tahapan dalam Data Mining

\section{B. Pengelompokan Data Mining}

Data Mining dibagi menjadi beberapa kelompok berdasarkan tugas yang dapat dilakukan yaitu: [1]

1. Deskripsi

Menggambarkan pola dan kecenderungan yang terdapat dalam data, deskripsi dari pola dan kecenderungan sering memberikan penjelasan untuk suatu pola atau kecenderungan.

2. Estimasi
Estimasi hampir sama dengan klasifikasi, kecuali variabel target estimasi lebih ke arah numerik dari pada ke arah kategori.

3. Prediksi

Dalam prediksi, nilai dari hasil akan ada di masa mendatang.

4. Klasifikasi

Dalam klasifikasi, terdapat target variabel katagori.

5. Pengklusteran

Merupakan pengelompokan record, pengamatan, atau memperhatikan dan membentuk kelas objekobjek yang memiliki kemiripan.

6. Asosiasi

Menemukan atribut yang muncul dalam satu waktu.

\section{Algoritma $C 4.5$}

Algoritma $C 4.5$ memiliki kelebihan utama yaitu dapat menghasilkan model berupa tree atau aturan yang mudah diinterpretasikan, memiliki tingkat akurasi yang dapat diterima, dapat menangani atribut bertipe diskrit dan numerik[5]. Algoritma C4.5 merupakan algoritma yang digunakan untuk membentuk decision tree berdasarkan kriteria-kriteria pembentuk decision [7]. Menurut[2] Rumus algoritma C4.5 terbagi menjadi 2 rumus, yang pertama rumus untuk mencari nilai Gain yaitu:

$$
\operatorname{Gain}(S, A)=\operatorname{Entropy}(S)-\sum_{i=1}^{n} \frac{\left|S_{i}\right|}{S} * \operatorname{Entropy}\left(S_{i}\right)
$$

Keterangan:

$$
\begin{aligned}
& \mathrm{S}=\text { himpunan kasus } \\
& \mathrm{A}=\text { fitur } \\
& \mathrm{n}=\text { jumlah partisi atribut } \mathrm{A} \\
& \left|\mathrm{S}_{i}\right|=\text { proporsi } \mathrm{S}_{i} \text { terhadap } \mathrm{S} \\
& |\mathrm{S}|=\text { jumlah kasus dalam } \mathrm{S}
\end{aligned}
$$

Dan rumus yang kedua adalah untuk mencari nilai Entropy, yaitu:

$$
\operatorname{Entropy}(S)=\sum_{i=1}^{n}-P_{i} * \log _{2} \quad P_{i}
$$

Keterangan:

$$
\begin{aligned}
& \mathrm{S}=\text { himpunan kasus } \\
& \mathrm{n}=\text { jumlah partisi } \mathrm{S} \\
& \mathrm{P}_{i}=\text { proporsi } \mathrm{S}_{i} \text { terhadap } \mathrm{S}
\end{aligned}
$$

\section{Decision Tree}

Decision tree adalah struktur flowchart yang mempunyai tree(pohon), di mana setiap simpul internal menandakan suatu tes atribut, setiap cabang 
merepresentasikan hasil tes, dan simpul daun merepresentasikan kelas atau distribusi kelas[8]. Decision tree adalah salah satu metode yang digunakan untuk pengklasifikasian dan prediksi karena memiliki kemudahan dalam interpretasi hasil. Decision tree dan algoritma $C 4.5$ merupakan dua model yang tidak terpisahkan, oleh karena itu untuk membangun sebuah decision tree, dibutuhkan algoritma C4.5[6].

Untuk mengklasifikasikan sampel yang tidak diketahui, nilai atribut dari sampel tersebut di uji oleh decision tree. Suatu jalur ditelusuri dari root ke node leaf yang memiliki prediksi kelas untuk sampel tertentu. Saat decision tree dibuat, kebanyakan dari cabang mungkin memperhatikan noise pada training data, tree prunning berusaha untuk mengidentifikasi dan membuat cabang-cabang tersebut dengan tujuan memperbaiki akurasi klasifikasi pada data yang tidak kelihatan[3].

\section{ANALISIS DAN PERANCANGAN}

\section{A. Analisis Pengumpulan Data}

Dalam penelitian ini, dilakukan pengumpulan data dengan mengambil objek penelitian pada data rekam jejak kinerja dosen dalam melaksanakan tri darma perguruan tinggi yang terhitung dari TA 2015 sd 2017. Data yang diperoleh dalam penelitian ini merupakan data yang diperoleh dari LPPM(Lembaga Publikasi dan Pengabdian Masyarakat) dan Lembaga Penjamin Mutu di STT Harapan Medan.

\section{B. Analisis Data}

Sebelum melakukan proses mining menggunakan algoritma C4.5, maka terlebih dahulu dilakukan proses analisis data. Data yang digunakan dan dianalisis yaitu data kinerja dosen STT Harapan Medan dalam melaksanakan tri darma perguruan tinggi, di mana pada data tersebut ada beberapa atribut yang digunakan untuk menentukan rekam jejak kinerja dosen yaitu meliputi; score publikasi, score pengabdian, kemampuan menjelaskan(A), kemampuan memotivasi(B), kemampuan mengadakan variasi(C), kemampuan mengelola kelas(D), kemampuan bertanya(E), sikap dosen $(F)$, fungsi $\operatorname{dosen}(\mathrm{G})$ dan penilaian $(\mathrm{H})$, seperti terlihat pada tabel 1 dibawah ini:
Tabel 1. Data Kinerja Tri Darma Perguruan Tinggi Dosen STT Harapan Medan

\begin{tabular}{|c|c|c|c|c|c|c|c|c|c|c|c|c|c|c|c|c|}
\hline \multirow[b]{2}{*}{ No } & \multirow{2}{*}{$\begin{array}{l}\text { Inisial } \\
\text { Dosen }\end{array}$} & \multicolumn{4}{|c|}{ Publikasi 2015 sd 2017) } & \multicolumn{3}{|c|}{ Pengabdian } & \multicolumn{8}{|c|}{ Pengejaran } \\
\hline & & \begin{tabular}{|c|} 
Jurtalal \\
Narional
\end{tabular} & $\begin{array}{c}\text { Jurnal } \\
\text { Intermasinal }\end{array}$ & \begin{tabular}{|l|} 
Seminar \\
Yasional \\
\end{tabular} & $\begin{array}{c}\text { Seminar } \\
\text { Intermasional }\end{array}$ & 2015 & 3016 & 2017 & A & B & c & D & E & $\mathrm{F}$ & $\theta$ & H \\
\hline 1 & AKH & 0 & 0 & 0 & 0 & 1 & 0 & 0 & 4,18 & 4,00 & 4,06 & 3,99 & 4,63 & 4,45 & 4,29 & 4,28 \\
\hline 2 & & 3 & 0 & 2 & 1 & 1 & 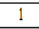 & & 4,07 & 4 & 4,05 & 4,25 & 4,25 & 4,23 & 4,11 & 4,02 \\
\hline 3 & HSF & 2 & 2 & & 0 & 4 & 1 & 1 & 4,13 & 4,28 & 4,14 & 3,87 & 4,52 & 4,47 & 4,38 & 4,05 \\
\hline 4 & N & 3 & 0 & 2 & 0 & 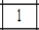 & 1 & 1 & 4,16 & 3,49 & 86 & 3,95 & \begin{tabular}{|l|l|}
4,47 \\
\end{tabular} & 3,94 & 4,10 & 4,10 \\
\hline 5 & DOD & 6 & & 2 & 1 & 2 & 2 & & 3,80 & 4,37 & 3,62 & 3,89 & 4,14 & 4,39 & 3,91 & 3,84 \\
\hline 6 & & 0 & c & 0 & & 0 & 1 & 0 & 4,41 & 4,11 & 4,06 & 4,29 & 4,33 & 4,17 & 4,27 & 4,03 \\
\hline 7 & AR & 2 & & 2 & 8 & 2 & 1 & 1 & 4,07 & 4,03 & 3,80 & 3,63 & 4,33 & 4,35 & 4,19 & 3,81 \\
\hline 8 & IFS & 3 & ( & 4 & 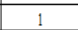 & $\square$ & 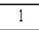 & 1 & 4,12 & 3,59 & 3,82 & 3,86 & 4,43 & 4,19 & 3,81 & 3,62 \\
\hline 9 & $\mathrm{R}$ & 2 & 7 & 3 & 7 & 4 & 80 & 0 & 3,71 & 4,15 & 90 & 4,07 & 3,86 & 3,87 & 3,63 & ,60 \\
\hline 10 & 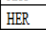 & 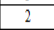 & & 1 & t & 1 & 0 & 4 & 4,43 & 4,07 & 3,93 & 4,32 & 4,36 & 4,43 & 4,24 & 4,08 \\
\hline 11 & $\mathbb{R}$ & 1 & & 1 & & 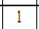 & 1 & 0 & 3,89 & 3,82 & 3,82 & 4,51 & 4,17 & 4,35 & 3,98 & 4,14 \\
\hline 12 & DV & 0 & & 0 & & 0 & 1 & 1 & 1,8 & 15 & 91 & 3,90 & 3,99 & 33 & 3,79 & 4,06 \\
\hline 3 & YUS & 1 & 0 & 0 & & $\therefore$ & 0 & 0 & 3,50 & 3,12 & 3,38 & 3,03 & 4,11 & 3,74 & 3,55 & 3,31 \\
\hline 14 & YYN & 3 & 3 & 2 & 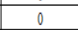 & 1 & 2 & 1 & 4,21 & 4,17 & 4,11 & 4,33 & 4,63 & 4,39 & 4,39 & 4,31 \\
\hline 15 & NNA & 2 & 3 & 2 & 7 & 2 & 1 & 1 & 3,64 & 3,18 & 3,43 & 4,01 & \begin{tabular}{|l|}
3,70 \\
\end{tabular} & 3,62 & 3,72 & 3,81 \\
\hline. & . & . & . & . & . & . & 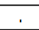 & . & . &. & . & . &. &. & - & \\
\hline & . & & & & & & & & & . & & & & & & \\
\hline . & . & & & & 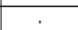 & 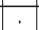 & & & 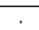 & & & & & & . & \\
\hline 180 & SAR & 1 & 0 & & & 1 & 0 & 1 & 4,44 & 4,43 & 4,30 & 4,49 & \begin{tabular}{|l}
4,83 \\
\end{tabular} & 4,72 & 4,52 & $4,47 \mid$ \\
\hline 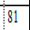 & YET & 0 & 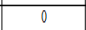 & & & 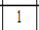 & 1 & 0 & 4,37 & 4,52 & \begin{tabular}{|l|}
4,27 \\
\end{tabular} & 4,61 & \begin{tabular}{|l|l}
4,57 \\
\end{tabular} & 4,80 & 4,35 & 4,50 \\
\hline 182 & YUN & 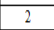 & 0 & 0 & & 10 & 1 & 1 & 4,21 & \begin{tabular}{|l|l}
4,17 \\
\end{tabular} & \begin{tabular}{|l|l|}
4,11 \\
\end{tabular} & 4,53 & 4,63 & 4,39 & 4,39 & 4,31 \\
\hline 183 & SFL & 0 & 0 & 0 & 1 & 1 & 0 & 0 & 4,41 & 4,47 & 4,47 & 4,16 & 4,60 & 4,99 & 438 & 4,35 \\
\hline 184 & ARS & 3 & 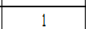 & 2 & 8 & 1 & 1 & 1 & 4,00 & 3,93 & \begin{tabular}{|l|}
3,91 \\
\end{tabular} & 4,08 & 2,96 & 4,01 & 3,93 & 3,87 \\
\hline 185 & LI & 2 & 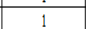 & 0 & & 1 & 1 & 0 & 1,82 & 3,90 & 3,79 & 4,27 & \begin{tabular}{|l|l}
4,45 \\
\end{tabular} & 4,32 & 4,10 & 4,1 \\
\hline
\end{tabular}

\section{Praprocessing Data}

Berdasarkan tabel 1, maka dilakukan proses praprocessing data yaitu dengan menggabungkan 8 atribut (A sd $\mathrm{H})$ dari 10 atribut input tersebut menjadi 1 atribut yaitu atribut "score pengajaran", sehingga atribut input yang digunakan ada 3 yaitu; score publikasi, score pengabdian dan score pengajaran, seperti terlihat pada tabel 2 di bawah ini.

Tabel 2. Atribut Input

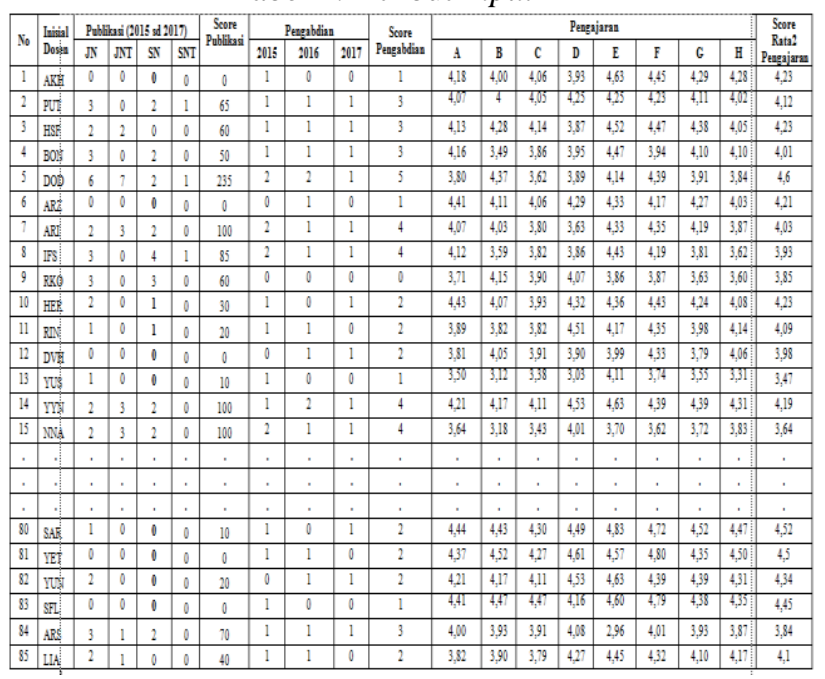

\section{Transformasi Data}

Berdasarkan 3 atribut input (score publikasi, score pengabdian dan score pengajaran), maka diperoleh 1 atribut output yang dibedakan menjadi 3 klas nilai kinerja yaitu kinerja "kurang", "cukup" dan 
"tinggi". Penentuan nilai kinerja dilihat berdasarkan score publikasi, score pengabdian dan score pengajaran.

Score publikasi diperoleh dari jumlah banyaknya publikasi dosen dikalikan dengan nilai angka kredit publikasi yang terdapat pada pedoman penilaian angka kredit kenaikan pangkat/jabatan akademik dosen. Kemudian score pengabdian diperoleh dari jumlah pengabdian masyarakat yang telah dilakukan dosen STT Harapan Medan. Dan untuk score pengajaran, score diperoleh dari penjumlahan nilai rata-rata point pengajaran $\mathrm{A}$ sd $\mathrm{H}$ pada masingmasing dosen. Berdasarkan hal tersebut maka dapat dilakukan transformasi pada data kinerja 85 dosen di STT Harapan Medan sebagai berikut pada tabel 3.

Tabel 3. Transformasi Data Kinerja Dosen STT Harapan Medan

\begin{tabular}{|c|c|c|c|c|c|}
\hline No & Inisial Dosen & $\begin{array}{c}\text { Score } \\
\text { Publikasi }\end{array}$ & $\begin{array}{c}\text { Score } \\
\text { Pengabdian }\end{array}$ & $\begin{array}{c}\text { Score } \\
\text { Pengajaran }\end{array}$ & Kinerja \\
\hline 1 & $\mathrm{AKH}$ & tidak ada & Kurang & baik & kurang \\
\hline 2 & PUT & cukup & Cukup & baik & cukup \\
\hline 3 & HSF & cukup & Cukup & baik & cukup \\
\hline 4 & BON & cukup & Cukup & baik & cukup \\
\hline 5 & DOD & ting $\mathrm{g} i$ & Tinggi & sangat baik & tinggi \\
\hline 6 & ARZ & tidak ada & Kurang & baik & kurang \\
\hline 7 & ARI & ting & Cukup & baik & tinggi \\
\hline 8 & IFS & ting gi & Cukup & baik & tinggi \\
\hline 9 & RKO & cukup & tidak ada & baik & kurang \\
\hline 10 & HER & kurang & Kurang & baik & kurang \\
\hline 11 & RIN & kurang & Kurang & baik & kurang \\
\hline 12 & DVH & tidak ada & Kurang & baik & kurang \\
\hline 13 & YUS & kurang & Kurang & baik & kurang \\
\hline 14 & YYN & ting gi & Cukup & baik & tinggi \\
\hline 15 & NNA & tinggi & Cukup & baik & tinggi \\
\hline 16 & IND & cukup & tidak ada & baik & kurang \\
\hline 17 & $\mathrm{ABM}$ & kurang & Kurang & baik & kurang \\
\hline 18 & FZI & tidak ada & Kurang & baik & kurang \\
\hline 19 & SPN & cukup & tidak ada & baik & kurang \\
\hline 20 & SRT & kurang & Kurang & baik & kurang \\
\hline$\cdot$ & & $\cdot$ & . &. & . \\
\hline & &. & . & - & \\
\hline . & & . & . & . & . \\
\hline & & & & & \\
\hline & & & & & \\
\hline 81 & YET & tidak ada & Kurang & baik & kurang \\
\hline 82 & YUN & kurang & Kurang & baik & kurang \\
\hline 83 & SFL & tidak ada & Kurang & baik & kurang \\
\hline 84 & ARS & cukup & Cukup & baik & cukup \\
\hline & & kurang & Kurang & baik & \\
\hline
\end{tabular}

\section{E. Merancang Decision Tree dengan Algoritma C4.5}

Berdasarkan tabel 3, maka dilakukan proses perhitungan Gain dan Entropy untuk menentukan akar (root) dari pohon keputusan dalam membantu menentukan rekam jejak kinerja dosen. Di bawah ini adalah hasil perhitungan Gain dan Entropy node 1, pada tabel 4.
Tabel 4. Hasil Perhitungan Gain dan Entropy pada Node 1.

\begin{tabular}{|l|c|c|c|c|c|c|c|c|}
\hline Node & Atribut & Kelas & $\begin{array}{c}\text { Jumlah } \\
\text { Kasus (S) }\end{array}$ & Kurang & Cukup & Tinggi & Entropy & Gain \\
\hline 1 & Total & & 85 & 55 & 17 & 13 & 1,285069 & \\
\cline { 2 - 9 } & Score & & & & & & & 1,025785 \\
\cline { 2 - 9 } & Publikasi & $\begin{array}{c}\text { Tidak } \\
\text { Ada }\end{array}$ & 15 & 15 & 0 & 0 & 0 & \\
\hline & kurang & 33 & 33 & 0 & 0 & 0 & \\
\hline & Cukup & 24 & 8 & 16 & 0 & 0,918296 & \\
\hline & tinggi & 13 & 0 & 0 & 13 & 0 & \\
\hline & Score & & & & & & & 0,755575 \\
\hline Pengabdan & $\begin{array}{c}\text { Tidak } \\
\text { Ada }\end{array}$ & 5 & 5 & 0 & 0 & 0 & \\
\hline & kurang & 44 & 44 & 0 & 0 & 0 & \\
\hline & Cukup & 29 & 3 & 17 & 9 & 1,314151 & \\
\hline & tinggi & 7 & 3 & 0 & 4 & 0,985228 & \\
\hline Score & Pengajaran & & & & & & & 0,100243 \\
\hline & Cukup & 2 & 2 & 0 & 0 & 0 & \\
\hline & baik & 81 & 54 & 16 & 11 & 1,243336 & \\
\hline & sangat & 2 & 0 & 0 & 2 & 0 & \\
\hline & baik & 2 & & & & & & \\
\hline
\end{tabular}

Dari hasil tabel 4, dapat diketahui atribut dengan Gain tertinggi adalah score publikasi, yaitu 1,025785. Dengan demikian score publikasi dapat dijadikan sebagai node akar. Dari hasil perhitungan nilai Gain dan Entropy pada node 1, maka dapat digambarkan decision tree sementara terlihat pada gambar 1 .

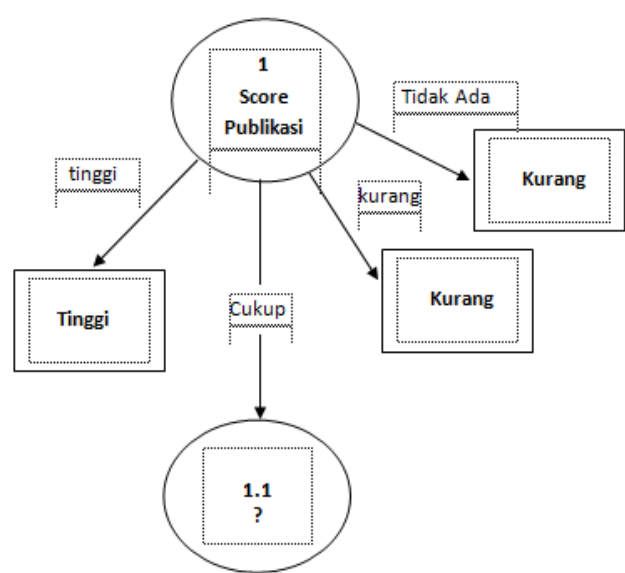

Gambar 1. Decision Tree Node 1 Penentuan Rekam Jejak Kinerja Dosen

Ada 4 nilai atribut dari "score publikasi" yaitu tidak ada, kurang, cukup dan tinggi. Berdasarkan data kinerja 85 dosen, maka score publikasi yang bernilai "tidak ada" dan "kurang" sudah mengklasifikasikan nilai menjadi 1 keputusan yaitu kinerja "kurang". Kemudian untuk score publikasi bernilai "tinggi" juga sudah mengklasifikasikan nilai menjadi 1 keputusan yaitu kinerja "tinggi". Sedangkan "score publikasi" yang bernilai "cukup" belum mengklasifikasikan nilai menjadi 1 keputusan, sehingga perlu dilakukan proses perhitungan Gain dan Entropy lebih lanjut, terlihat pada tabel 5. 
Tabel 5. Hasil Perhitungan Gain dan Entropy pada Node 1.1

\begin{tabular}{|c|c|c|c|c|c|c|c|c|}
\hline Node & Atribut & Kelas & $\begin{array}{c}\text { Jumlah } \\
\text { Kasus (S) }\end{array}$ & Kurang & Cukup & Tinggi & Entropy & Gain \\
\hline \multirow[t]{11}{*}{1} & Total & Publikasi- & & & & & & \\
\hline & & Cukup & 24 & 8 & 16 & 0 & 0,918296 & \\
\hline & Score & & & & & & & 0,918296 \\
\hline & Pengabdian & Tidak Ada & 5 & 5 & 0 & 0 & 0 & \\
\hline & & kurang & 3 & 3 & 0 & 0 & 0 & \\
\hline & & Cukup & 16 & 0 & 16 & 0 & 0 & \\
\hline & & tinggi & 0 & 0 & 0 & 0 & 0 & \\
\hline & Pengajaran & & & & & & & 0 \\
\hline & & Cukup & 0 & 0 & 0 & 0 & 0 & \\
\hline & & baik & 24 & 8 & 16 & 0 & 0,918296 & \\
\hline & & $\begin{array}{c}\text { sangat } \\
\text { baik }\end{array}$ & 0 & 0 & 0 & 0 & 0 & \\
\hline
\end{tabular}

Berdasarkan tabel 5 dapat diketahui bahwa atribut dengan Gain tertinggi adalah score pengabdian yaitu 0,918296 . Dengan demikian, score pengabdian dapat menjadi node cabang dari score publikasi bernilai "cukup". Untuk atribut score pengabdian memiliki 4 nilai atribut yaitu tidak ada, kurang, cukup dan tinggi. Ke-4 nilai atribut tersebut sudah mengklasifikasikan kasus menjadi satu keputusan, sehingga dapat digambarkan decision tree akhir dalam menentukan rekam jejak kinerja dosen STT Harapan Medan, terlihat pada gambar 2 .

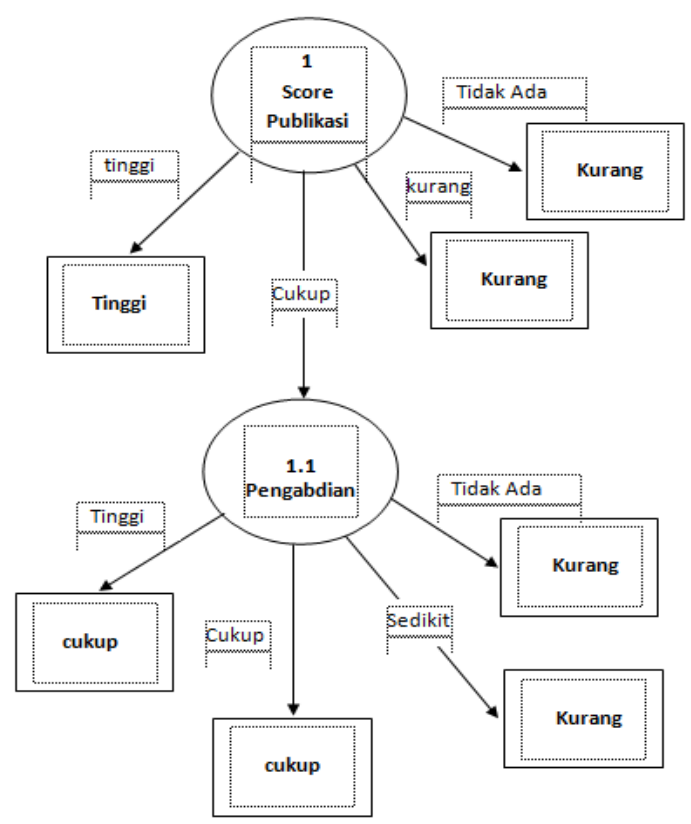

Gambar 2. Decision Tree Node 1.1 Penentuan Rekam Jejak Kinerja Dosen STT Harapan Medan

\section{IMPLEMENTASI}

Implementasi dilakukan menggunakan salah satu software Data Mining yaitu Rapid Miner 5.3.015. Semua atribut input dan atribut output disimpan dalam format $x l s x$, kemudian di import ke software Rapid Miner 5.3.015 dan menghasilkan decision tree sebagai berikut, pada gambar 3 .

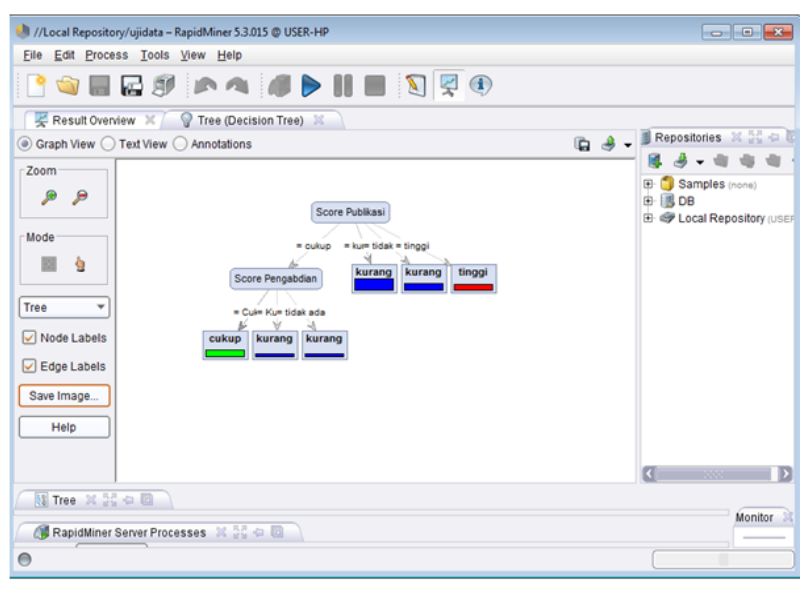

Gambar 3. Decision Tree Penentuan Rekam Jejak Kinerja Dosen STT Harapan Medan

Berdasarkan pengujian yang telah dilakukan, maka rules yang diperoleh dari hasil analisis penentuan rekam jejak kinerja dosen STT Harapan Medan menggunakan algoritma $C 4.5$ adalah sebagai berikut:

1. IF Score Publikasi "Kurang" THEN Kinerja "Kurang"

2. IF Score Publikasi "Tidak Ada" THEN Kinerja "Kurang"

3. IF Score Publikasi "Tinggi" THEN Kinerja "Tinggi"

4. IF Score Publikasi "Cukup" And Score Pengabdian "Cukup" THEN Kinerja "Cukup"

5. IF Score Publikasi "Cukup" And Score Pengabdian "Kurang" THEN Kinerja "Kurang"

6. IF Score Publikasi "Cukup" And Score Pengabdian "Tidak Ada" THEN Kinerja "Kurang"

\section{KESIMPULAN}

Setelah melakukan analisis, perancangan, impelementasi beserta pengujian dalam menerapkan algoritma C4.5 untuk menentukan rekam jejak kinerja dosen STT Harapan, maka diperoleh kesimpulan bahwa: 
1. Hasil decision tree penentuan rekam jejak kinerja dosen STTH Medan menghasilkan keputusan bahwa dosen yang berkinerja tinggi adalah dosen yang memiliki score publikasi tinggi.

2. Dosen yang berkinerja "cukup" adalah dosen yang memiliki score publikasi dan score pengabdian bernilai cukup.

3. Dosen yang berkinerja "kurang" adalah dosen yang memiliki score publikasi dan score pengabdian " Tidak Ada" dan "Kurang".

\section{REFERENSI}

[1] Gunadi, Goldie, Indra Sensue, "Penerapan Data Mining Market Basket Analysis Terhadap Data Penjualan Produk Buku dengan Menggunakan Algoritma Aprior dan Frequent Pattern Growth(Fb:Growth): Studi Kasus Percetakan Gramedia”, Jurnal Telematika M.Kom Vol. 4, No.1, 2012.

[2] Syahputra, Guntur, " Penerapan Algoritma C4.5 dalam Analisa Kelayakan Penerima Bonus Tahunan Pegawai(Studi Kasus: PT. Multi Pratama Nauli Medan)", Jurnal Mantik Penusa, Vol. 16, No. 2, Desember 2014.

[3] Ina, Wenefrida Tulit, "Klasifikasi Data Rekam Medis Berdasarkan Kode Penyakit International Menggunakan Algoritma C4.5", Jurnal Media Elektro, Vol. 1, No. 3, 2013.

[4] Luvia, Yuni Sara, Dedi Hartama n dkk, “ Penerapan Algoritma C4.5 untuk Klasifikasi Predikat Keberhasilan Mahasiswa di Amik Tunas Bangsa", JURASIK(Jurnal Riset Sistem Informasi \& Teknik Informatika), Vol. 1, No. 1, Juli 2016.

[5] Rismayanti, "Implementasi Algoritma C4.5 untuk Menentukan Penerima Beasiswa di STT Harapan Medan", Jurnal Media Infotama, Vol. 12, No. 2, September 2016.

[6] Rismayanti, "Decision Tree Penentuan Masa Studi Mahasiswa Prodi Teknik Informatika(Studi Kasus: Fakultas Teknik dan Komputer Univ. Harapan Medan)", QUERY: Jurnal Sistem Informasi, Vol. 2, No. 1, April 2018.

[7] Wajhillah, Rusda, Ita Yulianti, "Penerapan Algoritma C4.5 untuk Prediksi Penggunaan Jenis Kontrasepsi Berbasis Web", KLIK(Kumpulan Jurnal Ilmu Komputer)", Vol. 4, No. 2, September 2017.

[8] Sunjana, "Aplikasi Data Mining Data Mahasiswa dengan Metode Klasifikasi Decision Tree “, SNATI Yogyakarta, 2010.

[9] Swastina, Liliana, "Penerapan Algoritma C4.5 untuk Penentuan Jurusan Mahasiswa", Jurnal Gema Aktualita, Vol. 2, No. 1, 2013.

[10] Yunus, Mahmud, Harry Soekotjo n dkk, “ SPK Pemilihan Calon Pendonor Darah Potensial dengan Algoritma C4.5 dan Fuzzy Tahani”, Jurnal EECCIS, 2014, Vol.8 No1. 